\title{
Fragmentation in Global Energy Governance: Explaining the Creation of IRENA
}

\author{
Thijs Van de Graaf*
}

\section{Introduction}

In January 2009, 75 countries created the International Renewable Energy Agency (IRENA) at a founding conference in Bonn. The creation of IRENA highlights the growing concern over the unfolding energy and climate crises. Fossil fuels provide 80 percent of global energy while being responsible for almost 60 percent of total greenhouse gas emissions. ${ }^{1}$ Demand for these fuels is set to grow, while the conventional reserves are dwindling, sparking fears of "peak oil." In the wake of the recent shale gas and tight oil revolution, however, those fears have largely been replaced by concerns that fossil fuel abundance, not scarcity, is the most pressing problem, as it could lead us to overshoot our "carbon budget," the amount of carbon dioxide that can be emitted without jeopardizing our chances of staying below two degrees of average global warming. ${ }^{2}$ Renewable energy sources have thus come into sight as attractive alternatives to fossil fuels not only because they are abundant and clean, but also because they can help to bring energy services to the poor, while stimulating economic growth and job creation. Furthermore, when used and produced in a sustainable manner, renewable energy can reduce the pressure on natural resources by helping to combat deforestation, desertification and biodiversity loss. ${ }^{3}$

As of March 2013, an impressive total of 160 states have signed IRENA's treaty and 108 states, plus the EU, have ratified it. Remarkably, the new renewables organization is headquartered in Abu Dhabi, capital of the United Arab Emirates (UAE), a major oil and gas producer and a member of OPEC. Located in the UAE's capital for now, the secretariat will eventually move to Masdar, the zero-carbon city that is being constructed in the desert of Abu Dhabi. In April 2011, the Assembly - the highest decision-making body within IRENA - held its first-ever meeting, marking the operational launch of the new agency. Although IRENA has only a modest annual core budget of some US\$16 million in 2012, its creation in itself is significant. It is the first truly international organization that is hosted in the Middle East, ${ }^{4}$ the first international organization created under German leadership, and it is the first international organization that the US has joined in fifteen years.

Strikingly, the leading states behind IRENA's creation-Germany and, to a lesser extent, Spain and Denmark - are all founding members of the International Energy Agency (IEA). A child of the oil agitation of the 1970s, the IEA has worked on renewables for over three decades. Although its membership is exclusively reserved for developed countries, the IEA is the closest we currently have to a World Energy Organization. ${ }^{5}$ Nevertheless, instead of strengthening the IEA's existing capacities to work in the realm of renewable energy,

\footnotetext{
* Earlier versions of this article were presented at ISA's Annual Convention, Montréal, Canada, 16-19 March 2011, and at the workshop on "The Fragmentation of Global Environmental Governance: Causes, Consequences, and Responses" at the German Development Institute, Bonn, Germany, 29-30 August 2011. I thank the discussants and participants for their useful feedback. In addition, I am grateful to Jeff Colgan, Robert Keohane, Andrew Schrumm, Johannes Urpelainen, Harro van Asselt, Fariborz Zelli, and three anonymous reviewers for their valuable comments and suggestions. I also thank the officials whom I have interviewed. The Flemish Research Foundation (FWO) is gratefully acknowledged for a $\mathrm{PhD}$ fellowship. 1. IPCC 2007, 36; IEA 2010, 80.

2. Bill McKibben, “Global Warming’s Terrifying New Math,” Rolling Stone, 19 July 2012.

3. German Federal Government 2008.

4. Another energy organization, the International Energy Forum, has a small secretariat in Riyadh, Saudi Arabia, but compared to IRENA it is very weakly institutionalized and comprises less member states (about 89 in total). 5. Van de Graaf and Lesage 2009; Van de Graaf 2012.
} 
Germany and its partners decided to take the longer and more costly route of setting up a completely new organization with its own staff and headquarters. This begs two important theoretical questions: Why would member states of an international organization want to create an additional organization that would perform overlapping functions, thereby advancing the overall degree of fragmentation? And, relatedly, why would other members of the extant organization join the new institution?

Such acts of duplication are not only counterintuitive, they also contradict institutionalist theory. Recognizing the high transaction costs of crafting new organizations, standard institutionalist theory would expect states to use or modify the extant organizationfor example by expanding its resources, capacity or constituency-rather than to create an organization de novo whenever a new problem arises. Duffield aptly expresses this idea: "given the various costs involved in creating institutions, actors seeking to pursue common interests in a new area may prefer, wherever possible, to make use of preexisting institutions rather than start from scratch." ${ }^{\circ}$ The high costs of constructing new international organizations also differentiates de novo creation from related phenomena such as forum shopping or regime shifting, where actors transfer issues between existing institutional venues. $^{7}$

The young and burgeoning literature on institutional interplay and regime complexes also fails to solve the puzzle. Most of this literature focuses on the consequences rather than the origins of fragmented institutions. ${ }^{8}$ The most notable exception is Young, whose work on the politics of institutional linkages has directed attention to the strategic uses of regime formation. ${ }^{9}$ In contrast to regime theory's long-standing emphasis on the "stickiness" of institutions, Young argues that "nothing is self-evident or automatic about the choice of arenas for regime formation." $10 \mathrm{He}$ asserts that these choices should be understood as "products of organizational imperatives on the one hand and calculation of actor interests on the other." 11 Yet, despite Young's foundational work, still very little is known about the process of when, why and how states deliberately diverge from a certain institutional path and establish new institutions that overlap with existing ones. ${ }^{12}$

Heeding the call by Zelli and van Asselt for more theory-driven analyses of institutional complexity, ${ }^{13}$ this article provides an explanation for the central puzzle based on domestic preferences and the capture of institutions. Viewed through this lens, IRENA was part of an institutional hedging strategy instigated by domestic political actors in Germany, Spain and Denmark to counter the IEA's allegedly supportive stance toward the fossil and nuclear energy industries. The findings of this article suggest that, depending on the domestic preferences of a set of member states that have the capability to create international institutions, the transaction costs associated with institutional reform may surmount those of institutional creation. These insights help to understand the sources of dyadic institutional overlap and fragmentation.

Although the chief purpose of the article is to contribute to theory development, the case study in itself also advances research in a critical subfield of global environmental governance, namely energy sustainability. IRENA is the first major international organization that is set up with the prime objective to navigate and speed up the transition to more

6. Duffield 2003, 418.

7. Helfer 2004; Busch 2007.

8. Raustiala and Victor 2004; Alter and Meunier 2009; Biermann et al. 2009; Orsini et al. 2013.

9. Young 2002.

10. Young 2002, 118.

11. Young 2002, 120-121.

12. This article thus deals with a change of the energy regime complex. For an analysis of change within a complex, see Oberthür and Pożarowska article, this issue.

13. Zelli and van Asselt article, this issue. 
sustainable energy sources. By focusing on a transformation of the energy sector, it tackles head-on the root cause of some of the world's major environmental problems such as air pollution, acid rain, and climate change. In that respect, IRENA differs from the large body of international rules that has been adopted so far to manage the plethora of energy-related environmental externalities, such as the Kyoto Protocol. Even as those environmental treaties affect the energy sector, they do not lead to a radical departure from our current energy path. IRENA intends to do just that; yet, to date, the agency has attracted only scant scholarly attention, ${ }^{14}$ even within the emerging global energy governance literature. ${ }^{15}$

The article proceeds as follows. In the next section, I explain why the creation of additional institutions is highly unlikely according to conventional institutionalist thinking. In the third section, I develop two hypotheses that explain why, when and how actors could nevertheless diverge from the path and establish new institutions instead of using or changing existing ones. In the fourth section, I offer a process-tracing account of the case study. The fifth section engages the hypotheses with this evidence in an effort to interpret the observations and illustrate the practical validity of the proposed ideas. Examining only one case study precludes any general claims, but it does allow me to demonstrate the plausibility of the argument.

\section{Why Creating Overlapping Institutions is Difficult}

For the purposes of this article, international institutions may be defined as "explicit arrangements, negotiated among international actors, that prescribe, proscribe, and/or authorize behavior." ${ }^{16}$ Creating overlapping international institutions is difficult, first and foremost, because institutions are difficult to establish in general. The presence of complementary interests between states is in itself insufficient to explain why institutions are formed. For realist-inspired writers, it takes the presence of a hegemonic state that is willing to take the necessary steps for new institutional arrangements to come into being. Others point out that regime creation may also be spurred by the pressures of a severe and sudden crisis. ${ }^{17}$ The UN and the Bretton Woods institutions, for example, could not have gained the political momentum necessary if it were not for the end of the Second World War and the supply of leadership by the US. The same logic seems to apply to energy organizations, with the IEA having been created in reaction to the oil crisis of the 1970s and the Energy Charter Treaty (ECT) being an indirect product of the break-up of the Soviet Union. ${ }^{18}$ The fact that it usually takes a "transformational" or "after victory" moment for new regimes to come into being means that institutional creation does not occur very often.

Standard neoliberal-institutionalist theory further posits that international institutions, once established, are persistent and robust. Most famously, Keohane contends that "international regimes are easier to maintain than to construct." 19 In his view, states are inclined to stick with the arrangements they have, recognizing the high transaction costs of negotiating new ones. What makes bargaining over new institutions so costly is that it "involves strategic delay in reaching agreement, the investment of leaders' time, and the risk of their prestige." 20 Therefore, rational actors are generally expected to modify existing

\footnotetext{
14. Wright 2011; Meyer 2012.

15. Florini and Dubash 2011.

16. Koremenos et al. 2001, 762 .

17. Ikenberry 2001.

18. Colgan et al. 2012.

19. Keohane 1984, 102.

20. Stone 2009, 44.
} 
institutions to new circumstances, instead of abandoning them and erecting new institutions from scratch whenever a new cooperation problem emerges. ${ }^{21}$

Besides the transaction-cost argument, institutionalists also point to the mechanism of path dependence as an explanation for institutional stasis. Within institutionalized environments, there are several mechanisms of institutional reproduction at work that keep things moving along the same path. Institutions lock in vested interests, create sunk costs and generate increasing returns. ${ }^{22}$ The dynamic of increasing returns highlights the fact that the costs of switching from one institutional venue to another will tend to increase markedly over time. New institutions entail high fixed or start-up costs and they exhibit considerable learning effects. These costs can be avoided by simply working through existing organizations. Even when those extant institutions are nowhere near efficient or optimal to address a certain cooperation or coordination problem, states may stick to them anyway, for maintaining the status quo is an easy and low-cost option and states do not always behave as perfectly rational, utility-maximizing actors. As long as an existing regime performs essential functions passably well, state leaders are likely to engage in "satisficing" behavior. ${ }^{23}$

The proliferation of international institutions further raises the barrier to newcomers in the "institutional market." Over the past couple of years, the global institutional architecture has become markedly thicker and more densely populated than ever before, including in the sphere of energy. ${ }^{24}$ This implies that, when states are faced with either new problems that warrant international cooperation or with long-standing ones that have acquired more salience, they cannot start designing solutions from a "clean institutional slate." ${ }^{25}$ Regimes rarely emerge ex nihilio or out of chaos but "they are built on one another." ${ }^{26}$ Rising institutional density increases the chance that a new issue can be framed in such a way that it fits into an existing institutional arrangement.

Finally, institutionalist theory suggests that the existence of an institution can encourage further delegation of tasks. Applying the concept of "economies of scale" to the establishment of regimes, Keohane contends that, once a regime has been established, each additional issue could be included under the regime at a lower marginal cost. ${ }^{27}$ This mechanism of increasing returns to scale is the reason why we can expect to observe ever more extensive regimes across the board. It also explains why new specific agreements tend to be nested within existing regimes.

An interesting example of such nesting is the International Partnership for Energy Efficiency Cooperation (IPEEC), which was created by the G8 countries and their emerging partners in around the same period as IRENA. Like in the area of renewables, many international organizations were already engaged in the field of energy efficiency, so IPEEC's creators had to decide where they would house the new partnership. Eventually, IPEEC was created as a nested institution within the IEA. More precisely, IPEEC's secretariat is hosted at the IEA's headquarters in Paris, but it has a separate budget and is not accountable to the IEA's Governing Board. In other words, the creation of IPEEC proceeded along the lines predicted by institutionalist theory. This makes the creation of IRENA even more puzzling: why was a new institution on energy efficiency embedded within the IEA while another one, which emerged in the same period and was dedicated to renewable energy, was created outside of it?

21. Keohane 1984, 107; Duffield 2003.

22. Pierson 2000.

23. Keohane and Victor 2011.

24. Colgan et al. 2012.

25. Raustiala and Victor 2004, 280.

26. Keohane 1984, 79.

27. Keohane 1984, 90. 


\section{An Alternative Perspective: Institutional Capture and Hedging}

I depart from the premise that, rather than being prompted by purely functional imperatives or the need to solve a collective action problem, the migration of a governance site to an outside institution is likely to be the result of dissatisfaction with the outcomes under the existing arrangement. ${ }^{28}$ Member states that are dissatisfied with an existing organizationstates that I label "challengers" - have basically two options: they can "voice" (attempt to reform the organization); or, they can "exit" (withdraw from the organization). ${ }^{29}$ Given the high costs involved in exit, as discussed in the previous section, voice is the default option for challengers. I argue that their strategy changes when an international organization is captured by particular states or interest groups - a category of actors that I label "defenders."

The term "capture" is borrowed from Mansfield. ${ }^{30}$ When there is an actor or coalition of actors that is able to influence the distribution of benefits and costs among the members of an institution, and the institution appears to be impermeable to change, that institution may said to be captured. The concept is akin to Stigler's theory of "regulatory capture," which posits that, "as a rule, regulation is acquired by the industry and is designed and operated primarily for its benefits." 31

International organizations could be captured by a powerful state or a group of states. $^{32}$ Alternatively, international regulatory institutions could also be captured by particularistic interests, such as private firms, lobbyists, or sectoral organizations-whether they operate purely at the domestic level or transnationally. ${ }^{33}$ Or, international agencies could be captured by particular principled beliefs, ideologies or world views. The Bretton Woods institutions, for example, have long been bastions for neoliberal economic reforms, as exemplified by the Washington Consensus. Here, I will not extend the notion of institutional capture to the active role of ideas but focus instead on capture by states and interest groups. Ideational cleavages do come into play, albeit strictly within this actor-centric framework.

For analytical purposes, what matters is not only whether an institution is actually captured or not, but whether it is perceived as such in the eyes of relevant actors. Even if an institution favors certain interest groups or states, as long as it is not perceived as captured, institutional capture has no explanatory value for subsequent behavior. While perceptions at the state level matter, equally important is how institutions are perceived by domestic actors, because "international cooperation turns on domestic politics." 34 When the domestic politics in a member country turn against an international institution, that state may attempt to set up a "countervailing institution," defined as an institution created with the purpose of hedging against an extant institution. It is these domestic preferences that weaken the importance of the transaction-cost argument. Moravcsik has argued in a similar vein that, absent domestic or transnational support, institutions will not be sticky. ${ }^{35}$ The underlying assumption here is that states do not necessarily behave as unitary actors, but that state preferences are shaped by dominant domestic interests.

Of course, dissatisfaction alone is not sufficient to explain the emergence of overlapping institutions. Inspired by Kingdon, I hypothesize that two additional scope

28. Helfer 2004; Kahler and Lake 2009, 253.

29. Hirschman 1970.

30. Mansfield 1995.

31. Stigler 1971, 3.

32. Stone 2011.

33. Mattli and Woods 2009.

34. Gourevitch 1996, 350.

35. Moravcsik 1997, 537. 
conditions need to be met before a countervailing organization is created. ${ }^{36}$ First, the coalition of dissatisfied states has to have the capability to create a new institution on its own. For example, it does not suffice that the Maldives are dissatisfied with the global climate regime for them to be able to create a rival organization to the United Nations Framework Convention on Climate Change (UNFCCC). ${ }^{37}$ Second, this same set of states needs to believe that the creation of a new institution is the best solution to the problem at hand. This awareness could grow, for example, out of the failure of iterative reform efforts within the extant institution.

This leads me to a first hypothesis, which posits that when an international institution is captured and has lost domestic support in a (group of) powerful member state(s), the latter will attempt to create a countervailing institution.

Needless to say, "challenger" states who seek to build coalitions to establish countervailing institutions are bound to face stiff opposition from the "defender" states and bureaucrats that prefer the old institutional order. The defenders will try to block substantial changes in the organization's mandate and internal functioning, while retaining the incumbent forum as the focal point for the particular purview that is enshrined in its mandate. This means that they will also try to block any effort directed at creating another institution that could rival with the original institution or encroach upon its turf.

Should a countervailing institution be established anyway, however, those defender states may revise their strategies, especially if the new institution develops into a credible complement to the extant organization. This is the case if third-party states believe that they are better off by joining the new institution, for example, because it lowers transaction costs and provides information. ${ }^{38}$ Furthermore, the new institution could provide a rallying point that empowers and aligns domestic political forces in different states around the purpose of supporting the new institution. ${ }^{39}$ Symbolic reasons may matter as well. As the number of countries ratifying an environmental treaty increases, other countries may increasingly perceive the treaty as legitimate and adopt it themselves. ${ }^{40}$

Whatever the motives of these third-party states, the bottom line is that, to the extent that the countervailing organization gathers support, the defender states will come under pressure to join the new organization they initially opposed. Despite their preference for the original status quo, defender states may then find it rational to partake in the new organization. Faced with a fait accompli, it makes sense for them to jump the bandwagon and have a say in the new organization's design and activities, rather than to stay outside and risk seeing the new institution develop into a direction that is even farther away from their own preferences.

My second hypothesis hence claims that when a credible countervailing institution is created, states that prefer the institutional status quo ex ante will come under pressure to join the new institution.

\section{Case Description}

\section{The Road to IRENA}

The plans for an international agency dedicated to renewables preceded IRENA's creation by many years. The first multilateral deliberations on renewable energy date back to the early

\footnotetext{
36. Kingdon 1984.

37. Karlsson-Vinkhuyzen and McGee article, this issue.

38. Keohane 1984.

39. Drezner 2003.

40. Roberts et al. 2004.
} 
1960s. ${ }^{41}$ The issue was also addressed in the Brandt Report (1980), and the UN organized a major international conference on renewable energy in Nairobi in 1981. This conference examined the role of alternative energy sources not only in light of the oil shocks of the 1970s, which had severely hit the fragile economies of the third world, but also in response to the "other energy crisis" of that period, namely the rapid exhaustion of fuel wood as an energy source. No real progress was made though, and a proposal to create a special energy body within the World Bank was shelved due to opposition from the incoming Reagan administration in the US. ${ }^{42}$

One person has been trying to put the issue back onto the agenda since the 1990s: the late German politician Hermann Scheer. ${ }^{43}$ Scheer was a member of the Social Democratic Party (SPD) in Germany and has been a member of the German Parliament, the Bundestag, from 1980 until his unexpected death in October 2010. He has been president of two NGOs that have long campaigned for IRENA. In 1990, Scheer pleaded for the establishment of an International Solar Energy Agency. In the following months and years, he tried to sell his idea by approaching the UN Secretary-General, the US Senate, and the European Commission, but all in vain. In 2001, he came up with a modified proposal and presented a Memorandum for the Establishment of IRENA.

As a member of the executive committee of the SPD, Scheer introduced the demand to create IRENA into the government program of the SPD for the federal elections in the summer of 2002. At the initiative of Hans-Josef Fell, a member of parliament for the German Green Party (Bündnis 90/Die Grünen), the Green Party associated itself with this demand. In the elections, the governing coalition of the SPD and the Greens retained a narrow majority and continued in government with Gerhard Schröder as chancellor. In the new coalition agreement of October 2002, Scheer and Fell managed to include a commitment to launch an initiative for the establishment of IRENA.

At the same time, the UN World Summit on Sustainable Development had taken place in Johannesburg, from 26 August to 4 September 2002. German hopes for a strong resolution on the promotion of renewable energy quickly faded away in Johannesburg. In the wake of the failed negotiations, a group of countries came together at the end of the summit to found the Johannesburg Renewable Energy Coalition (JREC), a coalition of the willing to promote international cooperation on renewable energy. As a follow-up, Germany organized an international renewables conference in Bonn, in June 2004. Remarkably, the political declaration, which was adopted unanimously by high-level government representatives from 154 countries in Bonn, did not mention IRENA even once. The Bonn conference was the starting point of a series of international renewable energy conferences that have been held in Beijing (2005), Washington (2008), and Delhi (2010).

According to Scheer, the JREC grouping "was not meant to be taken seriously" 44 and the Bonn renewables conference was a "squandered opportunity." $45 \mathrm{He}$ considered the adherence to the "UN consensual spirit" to be one of the principal reasons for these failures, besides opposition from established institutions such as the "UN organizations and the World Bank, [which] are opposed to any agency like IRENA, simply on grounds of institutional competition." ${ }^{46}$ Indeed, the IEA claims to "have pushed back IRENA two or three times"

41. For an overview of the history of international cooperation on renewable energy, see Rowlands 2005.

42. Karlsson-Vinkhuyzen 2010, 182.

43. Unless stated otherwise, the following paragraphs are based on Eurosolar and WCRE 2009.

44. Scheer 2007, 163

45. Scheer 2007, 162.

46. Scheer 2007, 173. 
before it was actually established. ${ }^{47}$ Meanwhile, the IEA remained mired in sclerosis and proposals to reform its governance structure or to ramp up its budget for renewable energy were all defeated. ${ }^{48}$

Having learned from the Johannesburg and Bonn failures, the German government changed its tactics in January 2007 and initiated a series of bilateral talks with governments all over the world to get their support for establishing IRENA. Three special ambassadors were appointed for this task. At the 2008 renewable energy conference in Washington, Germany for the first time formally presented a concrete proposal for IRENA to other participating governments. Two preparatory conferences were held in Germany and Spain in 2008 and IRENA was finally established on January 26, 2009. The founding conference in Bonn, Germany, was attended by more than 120 national delegations from around the world; 75 of them became signatory states.

\section{IRENA's Institutional Set-up and Functions}

IRENA has three main organs: an Assembly, a Council, and a Secretariat. The Assembly is the supreme organ of the agency, which has the final word over all important decisions, including the adoption of the budget and the work program, the amendment of the Statute, and the appointment of the Director-General. It is composed of all member states, plus the EU, and meets once a year. Each member is attributed one vote and decisions on matters of substance are taken by consensus or near-consensus, that is, with no more than two members objecting. ${ }^{49}$ The Council consists of at least 11 but no more than 21 representatives of the members, elected for a term of two years by the Assembly. It convenes every six months and prepares the draft agenda for the Assembly. Within the Council, substantial decisions can be taken by a majority of two-thirds of the members. The Secretariat, finally, is entrusted with implementing the agency's work program and is headed by a Director-General who has a four-year office term.

From January 2009 until July 2010, when IRENA's statute entered into force, the signatory states gathered in the Preparatory Commission, an interim body to negotiate the agency's structures and initial work program. In June 2009, during the second session of the Preparatory Commission, it was decided that the Secretariat would be located in Masdar City, the prestigious low-carbon project under construction outside of Abu Dhabi. Once finished, the city will rely entirely on solar power and other renewable energy sources. At the same meeting, a French official, Hélène Pelosse, was elected as interim Director-General.

The choices for Masdar and Pelosse were clearly a disappointment for Germany. Hermann Scheer, who pioneered the idea of IRENA, had hoped that Bonn, which already hosts the UNFCCC secretariat, would become the headquarters and that he himself would be nominated to become IRENA's first Director-General. However, the German government had refrained from nominating him because it feared his candidacy would interfere with Bonn's application to host IRENA's headquarters. ${ }^{50}$ This was obviously a miscalculation on the part of the German government because in the end it got neither the Secretariat nor the DirectorGeneral. Moreover, some German officials suspected France of trying to win the top job inside the renewables organization so that it could move IRENA toward being a promoter of all low-carbon technologies - including nuclear energy. ${ }^{51}$ To sugar the pill, Bonn was elected

47. Interview with William C. Ramsay, deputy executive director of the IEA from 1999 to 2008, Brussels, 24 March 2009.

48. Van de Graaf and Lesage 2009.

49. Statute of IRENA, Article IX.

50. Interview with member state representative \#1, 26 April 2011.

51. Guardian, 28 June 2009. 
to host IRENA's Centre of Innovation and Technology, while Vienna became the Agency's Liaison Office for cooperation with other international organizations, most notably UNIDO, the IAEA and OPEC.

The choice for Abu Dhabi as the headquarters' location was the result of an impressive diplomatic lobby campaign that the UAE had set up, especially toward African countries. $^{52}$ Moreover, the UAE promised to invest massively in IRENA. While Germany only offered some US\$11 million, the UAE offered no less than US\$136 million over the first six years. In addition, the UAE pledged to cover the entire costs for the logistics of the new agency so that the member states' contributions could be directly used for the payment of salaries and to finance the implementation of its activities. ${ }^{53}$ The Abu Dhabi Fund for Development also promised an amount of US\$50 million each year, for the first seven years, to finance renewable energy projects in developing countries that are recommended by IRENA.

IRENA's overall goal is to "promote the widespread and increased adoption and the

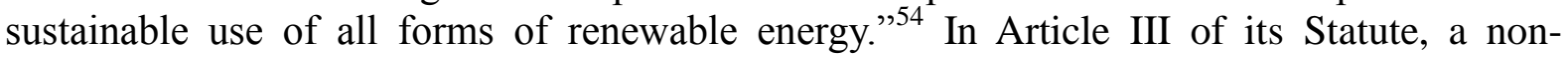
exhaustive list of renewable energy sources is presented: bioenergy, geothermal energy, hydropower, ocean energy, solar energy, and wind power. According to its statute, IRENA, among other things, conducts policy analysis and advice, improves technology transfer, offers capacity building, provides advice on financing, and stimulates research. ${ }^{55}$ IRENA is not able to enact binding decisions on its member states, nor does it act as a development bank.

\section{Early Leadership and Budgetary Problems}

The first two years after the signing of IRENA's treaty were very turbulent. Less than 18 months after being elected as interim director-general, Hélène Pelosse stepped down on October 19, 2010. In an interview, Pelosse accused the UAE of pressurizing her to resign because she took to make gender parity a high priority at the new agency. Moreover, she publicly accused the UAE government of intimidation by intruding into her home, bugging her phone and office, and searching her baggage. ${ }^{56}$

Just a few days before Pelosse's resignation, Scheer passed away after suffering a heart attack. In some interviews right before his death, Scheer had defended Pelosse and stated that IRENA's administrative committee, a body mandated to help set up the agency, had obstructed her in her work. However, an anonymous member of IRENA's administrative committee, rebuked these accusations and said that Pelosse had made several missteps, such as putting on the website that she is opposed to carbon capture and storage, as well as nuclear energy. ${ }^{57}$

A number of member states, both developed and developing, were also dissatisfied with what they saw as the "financial mismanagement" by Pelosse and her failure to put into practice "good accounting standards." ${ }^{\text {As }}$ As a result, they withheld the financial support they had promised. Among these countries, the US (which had promised about US\$3 million) and Japan (which had promised close to US\$2.2 million) stood out as the largest defectors. ${ }^{59}$ In

52. Interview with member state representative \#1, 26 April 2011.

53. Interview with member state representative \#2, 15 October 2010.

54. Statute of IRENA, Article II.

55. Statute of IRENA, Article IV.

56. Agence France Presse, 25 October 2010.

57. New York Times, 29 November 2010.

58. Interview with member state representative \#1, 26 April 2011.

59. Annual report of the Interim Director-General to the fifth session of the Preparatory Commission for the International Renewable Energy Agency on the implementation of the 2010 Work Programme and Budget, available at http://www.irena.org/documents/uploadDocuments/PC.5_2.pdf, accessed 25 March 2013. 
January 2010, the Preparatory Commission had adopted a budget of US $\$ 14$ million, but by June only about US $\$ 5$ million had been paid. The agency had to downsize its programs and freeze all expenditures in June 2010. ${ }^{60}$ Eventually, these budgetary problems were rectified, largely because the UAE stepped in with a large amount of additional cash. ${ }^{61}$ In October 2010, a new interim Director-General was appointed, Adnan Amin, with broad support from the membership.

\section{Explaining the Observed Institutional Dynamics}

\section{Venue Selection}

At the moment of IRENA's creation, there were a lot of alternative institutional homes in which the new institution could have been nested. The most obvious alternative to creating a new body would have been to reform the IEA, which had been working on renewables for years. In 1999, the IEA had created a renewable energy unit to provide support to the Working Party on Renewable Energy Technologies, which was itself created in 1982 as an advisory body on renewable energy. Moreover, the agency has maintained a "policies and measures" database on renewable energy since 2004, operated a small dozen of Implementing Agreements on specific renewable energy technologies, and renewable energy has been a part of its data collection efforts more generally. In the eyes of IRENA's founding fathers, however, the IEA was not an appropriate venue. Indeed, as one interlocutor described it, "a reform of the IEA was never really considered, either out of practicality or out of ideology."

On the practical side, clearly, there were some obstacles to an enhanced IEA role in renewables, most notably that the IEA's activities are largely limited to the OECD countries, that its renewable energy work is underfinanced and understaffed, and that it does not have a wide expertise in training, capacity-building and technical assistance toward developing countries. In the eyes of some observers, though, these practical obstacles could have easily been overcome. ${ }^{63}$ For example, IRENA could have been nested within the IEA in the same way as the IPEEC. Or, the IEA's renewable energy unit could have been upgraded and given more human and financial resources from the core budget.

The functional argument that IRENA's creators have used to justify their creation of a standalone organization could even be used against them. Former IEA Director Claude Mandil believes that:

organizations that focus on small pieces of the overall energy puzzle are not good because agencies dedicated to one energy type become lobbyist agencies. The problem is not in the IEA's view to be pro or against renewables but to solve the energy security and climate change issues. In my view, renewables should be considered as a tool, not as an objective per se. ${ }^{64}$

A more important reason for establishing IRENA as a standalone organization seems to be of political nature. In the eyes of the German government, the existing "political structures often put renewable energy at a disadvantage compared to other energy sources." It strongly believed that renewable energy needed an "additional push" because it lagged

60. Interview with member state representative \#1, 26 April 2011.

61. Interview with member state representative \#2, 15 October 2010.

62. Interview member state representative \#3, 26 April 2011.

63. Interview member state representative \#3, 26 April 2011

64. Interview with Claude Mandil, Executive Director of the IEA from 2003 to 2007, Paris, 9 March 2010.

65. German Federal Government 2008, 7. 
behind fossil and nuclear energy in terms of market structures, technology development, and established industries. ${ }^{66}$ Berlin was convinced that the IEA's mandate was too broad to ensure that the agency could provide a visionary leadership on renewable energy. The German government judged that the IEA's analyses tended to focus on large-scale energy supply, "without offering advice on adapting markets to more decentralized forms of energy" and "without fully reflecting the potential of renewable energy." 67

More specifically, German, Danish and Spanish interest groups and NGOs were dissatisfied with the IEA because they saw this agency as a lobby for fossil fuels and nuclear, underestimating the potential of renewable sources of energy. In early 2009, the Energy Watch Group, an international coalition of politicians and scientists headquartered in Germany, accused the IEA of blocking a global switch to renewables. It pointed out that, in 1998, the IEA had predicted that global wind electricity generation would total 47.7 gigawatt by 2020 . The target was already reached in 2004, sixteen years earlier than predicted. In 2002 , the IEA revised its estimate to 104 gigawatt by 2020, a capacity that was exceeded by the summer of $2008 .{ }^{68}$ To the authors of the report and to Scheer, these wrong projections evidenced that the IEA "leaves no stone unturned when it comes to emphasizing the longterm indispensability of nuclear and fossil energy." 69

In line with my first hypothesis, it was the perception of the IEA as a captured institution that helped to spur a coalition of like-minded states to create a countervailing organization, whose framing of the problem was beneficial to their own interests. Among the actors most eager to establish IRENA an ulterior motive might have been to advance the interests of the strong renewable energy companies they host. Within Germany, Denmark, and Spain, there are strong corporate interests in the renewable energy sector. As Table 1 illustrates, no less than seven of the top ten wind turbine manufacturers (in order of production) in 2007 were based in one of the three leading states behind the creation of IRENA. This same set of countries also figures in the top ranks with regard to other renewable energy indicators, including grid-connected solar power and investment in new renewable energy capacity. ${ }^{70}$

\section{Table 1}

The Top Ten Wind Turbine Manufacturers in Order of Production (2007) $)^{71}$

\begin{tabular}{llll}
\hline Rank & Company & Country of origin & IRENA coalition \\
\hline 1 & Vestas & Denmark & Yes \\
2 & Gamesa & Spain & Yes \\
3 & GE & US & No \\
4 & Enercon & Germany & Yes \\
5 & Suzlon & India & No \\
6 & Siemens & Germany & Yes \\
7 & Nordex & Germany & Yes \\
8 & Repower & Germany & Yes \\
9 & Acciona & Spain & Yes
\end{tabular}

66. German Federal Government 2008, 7.

67. German Federal Government 2008, 9.

68. Rechsteiner 2008, 10.

69. Scheer 2007, 174.

70. REN21 2008, 8.

71. REN21 2008, 18. 


\section{Momentum}

Creating an outside institution is risky because the "defender states" are likely not to join it. This risk was clearly present for IRENA because, initially, it failed to mobilize support from some key countries. Conspicuously absent from the 75 original signatories were G8 countries Canada, Japan, Russia, the UK, and the US; and global South leaders such as Brazil, China, India, Mexico and South Africa.

Only drop by drop did many G20 countries decide to join, as illustrated in Figure 1. China's announcement in January 2013 that it plans to join IRENA confirms this pattern. Today, 26 out of 28 IEA member countries have signed onto IRENA's statute. The two remaining IEA countries are Canada and Hungary, although it is clear that within both countries political forces exist that are supportive of IRENA. Apart from these countries, some of the most remarkable remaining absentees are Brazil and Russia. The key here, however, is not to explain why a few major countries have remained outside of IRENA but to explain why so many of them have joined the agency in spite of their initial reticence.

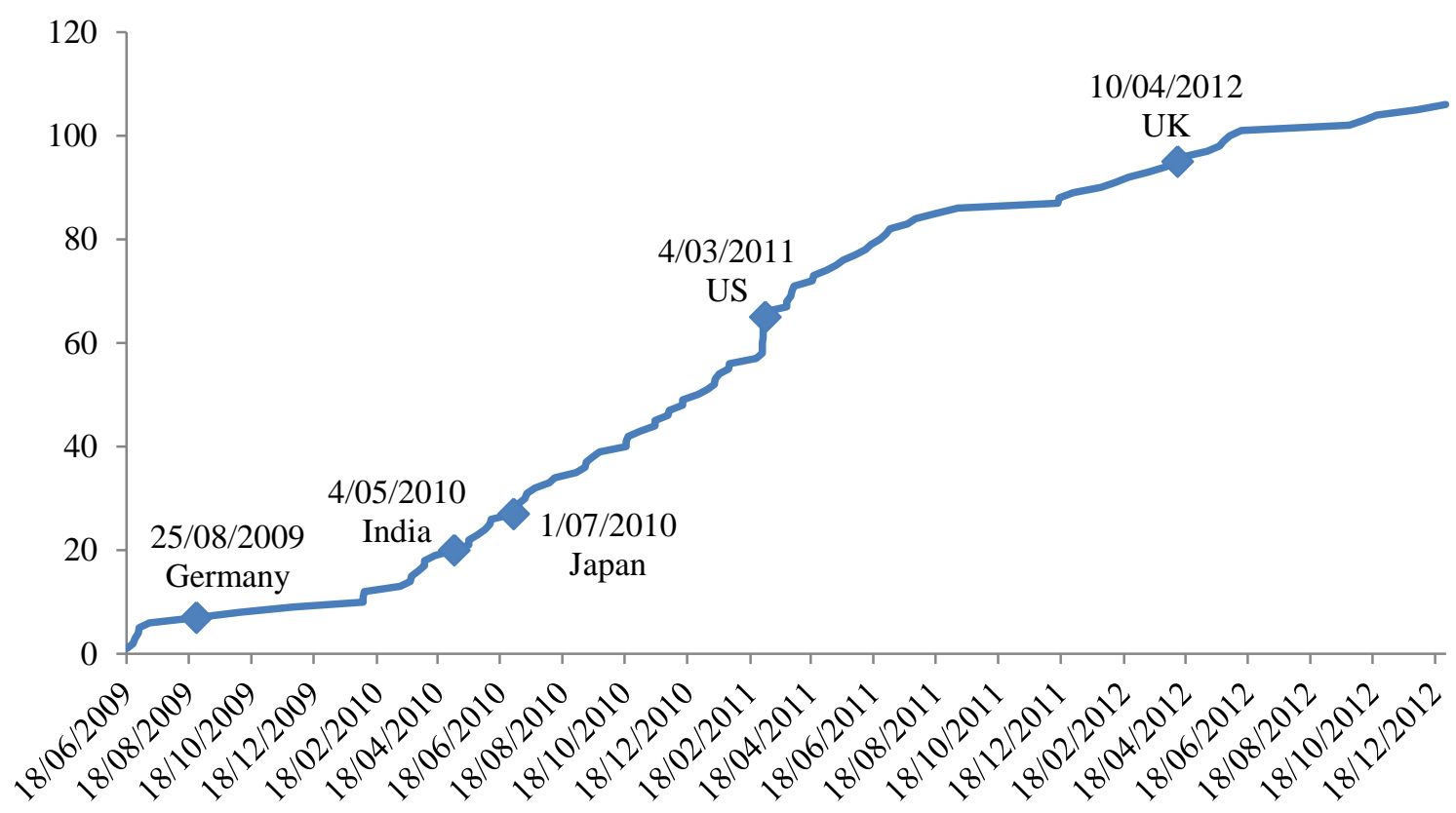

Figure 1.

Ratifications of IRENA's Statute (up until January 2013) ${ }^{72}$

This new momentum is indeed remarkable, especially if contrasted with the lack of progress at the 2002 Johannesburg summit and the 2004 Bonn renewables conference. Part of the explanation is that the German government changed its strategy. In 2004, the German government deemed it was more important to have everybody on board-even the Bush administration and OPEC - and produce a correspondingly meaningless text. As from 2008, Berlin changed its tactics and forged a coalition of the willing instead of trying to create a bland consensus. This strategy proved successful and other countries were persuaded to join. One reason is that, confronted with a fait accompli, many governments decided that it was

72. Author's creation based on data from http://www.irena.org. 
better to enter the negotiations now and have a say in the new agency's institutional set up, rather than joining later and having no say in these matters at all. Indeed, right before he passed away in October 2010, Scheer had said: "some countries appear to have joined IRENA mainly to influence its program, while maintaining a minimalist view of the role for renewable energy in solutions to climate change."73

Another explanation for the increased momentum is posturing. The US, for example, "was never in favor of IRENA and saw no reason to create another international organization," which it regarded as "a product of zealous European political posturing." Yet, eventually, Washington did become a member because "coming off the Bush administration it was a fairly inexpensive way to demonstrate a different approach of the Obama Administration to lower carbon options." illustrates the symbolic value of creating and joining international institutions, serving as a signal of state leaders towards domestic or foreign audiences.

In short, we can observe a pattern that is consistent with my second hypothesis. Developed countries that initially opposed IRENA, such as the US and the UK, have eventually succumbed to pressures to join the renewables agency. They did so for a variety of reasons: the fact that IRENA was going ahead anyway, the entry of a growing number of third countries, and the symbolic and bargaining benefits of joining the new agency.

The large number of states that have joined IRENA since 2009, for various reasons and with different expectations, explains the apparent paradox in the agency's institutional design: despite the rejection of the UN as a proper institutional home for IRENA, the new agency's institutional design is characterized by a preference for UN-type rules and structures. While many of the criticisms of previous renewable energy institutions had been that they lack teeth and implementation, IRENA has adopted statutes that entrench it in a system prone to sclerosis, relying on consensus (or near-consensus) in its main decisionmaking bodies despite its large membership base.

\section{Conclusions}

This article has analyzed the phenomenon whereby states create overlapping institutions, thus advancing the overall degree of fragmentation. It has also proposed an explanation for it, based on the capture of institutions by particular states or interest groups. The capture of an institution could spur the creation of a countervailing organization if there exists a sufficiently strong coalition of dissatisfied states in which the incumbent institution has lost domestic support. The creation of a credible countervailing institution generates pressure on the outsiders to join the new institution to influence the bargaining process, to satisfy a domestic constituency, and/or to reap reputational payoffs.

The question remains whether IRENA will have real teeth, besides being a talkingshop and cheerleader for renewables. After a rocky start, the seasoned UN official Amin has put the agency back on track since he took office in late $2010 .{ }^{75}$ Since IRENA has only been a fully functioning organization for about two years, the jury is still out on whether it will succeed in lowering information asymmetries, building political consensus, and helping developing countries leapfrog the fossil fuel-based economic development model. These are

73. New York Times, 29 November 2010.

74. Interview with William C. Ramsay, deputy executive director of the IEA from 1999 to 2008, Brussels, 24 March 2009.

75. Interview with Adnan Z. Amin, Director-General of IRENA, London, 25 April 2012. See also Thijs Van de Graaf, "IRENA Should Be a Platform Where Anybody Who Has Good Ideas Is Welcomed," European Energy Review, 24 May 2012. 
probably the kinds of functions that IRENA's creators had in mind when they pushed for a new multilateral initiative on renewable energy.

However, such a functionalist argument is insufficient to explain the emergence of IRENA because it fails to grasp why Germany and others were willing to pay the significant start-up costs involved in creating a standalone organization, particularly given that the IEA could be retooled to take on the same tasks that IRENA is performing now. Indeed, the push to create IRENA can be viewed partly as a symbolic action, taken for internal German political reasons, with the organization given a headquarters for prestige reasons in Abu Dhabi. In that respect, the case study challenges the strict functionalist understanding of institutions as it reveals that not all institutions are created with the sole purpose of reducing transaction and information costs. Politicians sometimes create international institutions on "pet" issues for purely domestic reasons, or as a signal to international audiences, rather than for addressing a collective action problem, adding to the overall fragmentation of the global institutional architecture.

The case study serves as a reminder that international organizations are not neutral vehicles but embody certain interests and principled beliefs. Examining the driving forces behind the creation of overlapping institutions can thus be revealing of the contentious issues, the politics, and the ideological cleavages that surround those institutions and the areas they operate in. The creation of a specialized renewable energy agency raises the specter of (further) institutional fragmentation in global energy governance along sectoral lines, with each sector having its own international institution. Sectoral institutions are often captive to their constituencies and tend to acquire a "booster-club mentality." "Every sectoral grouping thus tends to defend "its" fuel of choice. IRENA could become no less guilty of this dynamic than the IEA or the IAEA.

This does not mean that IRENA and the IEA will necessarily be locked in parochial turf wars and ideological battles over energy policy. Indeed, there are signs that they are moving into the direction of "cooperative fragmentation." 77 For one thing, in January 2012, the heads of both agencies have signed a partnership agreement and have agreed to collaborate closely on issues like data collection. ${ }^{78}$ For another, there are tentative signs that the creation of IRENA has served as a salutary shock to the IEA. In September 2008, the IEA upgraded its renewable energy "unit" into a "division," staffed by 9 full-time analysts, as a sign that the agency is aware of the urgent need to accelerate the large-scale penetration of renewable energy technologies into the market to reduce carbon dioxide emissions. In addition, the IEA has expressed itself unusually positive in two recent reports on solar energy. ${ }^{79}$ While it is difficult to establish a causal connection, it might be that the mere existence of IRENA has made the IEA more responsive to demands for change as it has opened up opportunities for forum-shopping.

More research on inter-institutional learning and institutional interaction is needed to examine the nature of such causalities ${ }^{80}$ Altogether, the findings of this article raise important questions for the future of global energy and climate governance and call for new research into institutional capture, competing organizations, and the symbolic benefits of cooperation.

\section{References}

76. Interview with member state representative \#3, 26 April 2011.

77. Zürn and Faude article, this issue.

78. Thijs Van de Graaf, "How IRENA is Reshaping the Global Energy Architecture," European Energy Review, 29 March 2012.

79. “A Solar Revolution at the IEA,” European Energy Review, 4 June 2010.

80. Oberthür and Gehring 2011. 
Alter, Karen J., and Sophie Meunier. 2009. The Politics of International Regime Complexity. Perspectives on Politics 7 (1): 13-24.

Biermann, Frank, Philipp Pattberg, Harro van Asselt, and Fariborz Zelli. 2009. The Fragmentation of Global Governance Architectures: A Framework for Analysis. Global Environmental Politics 9 (4): 14-40.

Busch, Marc L. 2007. Overlapping Institutions, Forum Shopping, and Dispute Settlement in International Trade. International Organization 61 (4): 735-761.

Colgan, Jeff D., Robert O. Keohane, and Thijs Van de Graaf. 2012. Punctuated Equilibrium in the Energy Regime Complex. Review of International Organizations 7 (2): 117143.

Drezner, Daniel W. 2003. Locating the Proper Authorities: The Interaction of Domestic and International Institutions. Ann Arbor, MI: University of Michigan Press.

Duffield, John S. 2003. The Limits of "Rational Design". International Organization 57 (2): 411-430.

Eurosolar and World Council for Renewable Energy (WCRE). 2009. The Long Road to IRENA: From the Idea to the Foundation of the International Renewable Energy Agency. Bochum: Ponte Press.

Florini, Ann, and Navroz K. Dubash. 2011. Introduction to the Special Issue: Governing Energy in a Fragmented World. Global Policy S1 (2): 1-5.

German Federal Government. 2008. The Case for an International Renewable Energy Agency (IRENA). Preparatory Conference for the Foundation of IRENA, April 10-11.

Gourevitch, Peter. 1996. Squaring the Circle: The Domestic Sources of International Cooperation. International Organization 50 (2): 349-373.

Helfer, Laurence R. 2004. Regime Shifting: The TRIPs Agreement and New Dynamics of International Intellectual Property Lawmaking. Yale Journal of International Law 29 (1): 1-83.

Hirschman, Albert O. 1970. Exit, Voice, and Loyalty: Response to Decline in Firms, Organizations, and States. Cambridge, MA: Harvard University Press.

IEA. 2010. World Energy Outlook. Paris: OECD/IEA.

Ikenberry, G. John. 2001. After Victory: Institutions, Strategic Restraint, and the Rebuilding of Order After Major Wars. Princeton, NJ: Princeton University Press.

IPCC. 2007. Climate Change 2007: Synthesis Report. Geneva: IPCC.

Kahler, Miles and David A. Lake. 2009. Economic Integration and Global Governance: Why So Little Supranationalism? In The Politics of Global Regulation, edited by Walter Mattli and Ngaire Woods, 242-275. Princeton, NJ: Princeton University Press.

Karlsson-Vinkhuyzen, Sylvia I. 2010. The United Nations and Global Energy Governance: Past Challenges, Future Choices. Global Change, Peace \& Security 22 (2): 175-195.

Keohane, Robert O. 1984. After Hegemony: Cooperation and Discord in the World Political Economy. Princeton, NJ: Princeton University Press.

Keohane, Robert O., and David G. Victor. 2011. The Regime Complex for Climate Change. Perspectives on Politics 9 (1): 7-23.

Kingdon, John W. 1984. Agendas, Alternatives, and Public Policies. Boston: Little, Brown.

Koremenos, Barbara, Charles Lipson, and Duncan Snidal. 2001. The Rational Design of International Institutions. International Organization 55 (4): 761-799.

Mansfield, Edward D. 1995. International Institutions and Economic Sanctions. World Politics 47 (4): 575-605.

Mattli, Walter, and Ngaire Woods. 2009. In Whose Benefit? Explaining Regulatory Change in Global Politics. In The Politics of Global Regulation, edited by Walter Mattli and Ngaire Woods, 1-43. Princeton, NJ: Princeton University Press. 
Meyer, Timothy. 2012. Global Public Goods, Governance Risk, and International Energy. Duke Journal of Comparative \& International Law 22 (3): 319-348.

Moravcsik, Andrew. 1997. Taking Preferences Seriously: A Liberal Theory of International Politics. International Organization 51 (4): 513-553.

Oberthür, Sebastian, and Thomas Gehring. 2011. Institutional Interaction: Ten Years of Scholarly Development. In Managing Institutional Complexity: Regime Interplay and Global Environmental Change, edited by Sebastian Oberthür and Olav Schram Stokke, 25-58. Cambridge, MA: MIT Press.

Orsini, Amandine, Jean-Frédéric Morin, and Oran R. Young. 2013. Regime Complexes: A Buzz, a Boom or a Boost for Global Governance? Global Governance 19 (1): 27-39.

Pierson, Paul. 2000. Increasing Returns, Path Dependence, and the Study of Politics. The American Political Science Review 94 (2): 251-267.

Raustiala, Kal, and David G. Victor. 2004. The Regime Complex for Plant Genetic Resources. International Organization 58 (2): 277-309.

Rechsteiner, Rudolf. 2008. Wind Power in Context: A Clean Revolution in the Energy Sector. Berlin: Energy Watch Group and Ludwig-Boelkow-Foundation.

Renewable Energy Policy Network for the 21st Century (REN21). 2008. Renewables 2007: Global Status Report. Paris: REN21 Secretariat.

Roberts, J. Timmons, Bradley C. Parks, and Alexis A. Vasquez. 2004. Who Ratifies Environmental Treaties and Why? Institutionalism, Structuralism and Participation by 192 Nations in 22 Treaties. Global Environmental Politics 4 (3): 22-64.

Rowlands, Ian H. 2005. Renewable Energy and International Politics. In Handbook of Global Environmental Politics, edited by Peter Dauvergne, 78-94. Cheltenham: Edward Elgar.

Scheer, Hermann. 2007. Energy Autonomy: The Economic, Social and Technological Case for Renewable Energy. London, UK: Earthscan.

Stigler, George. 1971. The Theory of Economic Regulation. Bell Journal of Economics and Management Science 2 (1): 3-21.

Stone, Randall W. 2009. Institutions, Power, and Interdependence. In Power, Interdependence, and Nonstate Actors in World Politics, edited by Helen Milner and Andrew Moravcsik, 31-49. Princeton, NJ: Princeton University Press.

Stone, Randall W. 2011. Controlling Institutions: International Organizations and the Global Economy. Cambridge, UK: Cambridge University Press.

Van de Graaf, Thijs. 2012. Obsolete or Resurgent? The International Energy Agency in a Changing Global Landscape. Energy Policy 48: 233-241.

Van de Graaf, Thijs, and Dries Lesage. 2009. The International Energy Agency After 35 Years: Reform Needs and Institutional Adaptability. The Review of International Organizations 4 (3): 293-317.

Wright, Glen. 2011. The International Renewable Energy Agency: A Global Voice for the Renewable Energy Era? Renewable Energy Law \& Policy Review 2 (4): 251-268.

Young, Oran R. 2002. The Institutional Dimensions of Environmental Change: Fit, Interplay, and Scale. Cambridge, MA: MIT Press. 